\title{
IMPACT OF PANDEMIC COVID-19 ON THE LEGAL REGULATION OF WORLD TRADE ACTIVITY USING THE EXAMPLE OF THE MEDICAL SUPPLIES
}

DOl: 10.36740/WLek202007139

\author{
Farouq Ahmad Faleh Alazzam, Ali Jabbar Saleh, Khaled Khalaf Abed Rabbo Aldrou \\ JADARA UNIVERSITY, IRBID, JORDAN
}

\begin{abstract}
The aim of the article is a theoretical and methodological justification for strengthening the role of international trade in medicines and equipment during the COVID-19 pandemic, to establish the benefits of free trade, to develop important international trade policy priorities in this field.

Materials and methods: Legislation of foreign countries and international organizations, statistical data published by international organizations are the materials of the research. Methods of analysis, synthesis, generalization were applied during the research.

Conclusions: It has been proved that the legal regulation of world trade activity by medical supplies are increasingly playing more important roles in the implementation of international development goals. The authors have offered three priorities to all countries: to cooperate globally around the deployment of life-saving medical supplies, publicly commit all countries not to implement export bans or limits on relevant medical supplies; to control all trade measures countries have taken in response to the COVID-19 outbreak; to bring together in a global form measures and procedures to eliminate this phenomenon.
\end{abstract}

KEY WORDS: global health, public health, international law, international trade, international relations, international organizations, medical supplies, devices and equipment, trade policy

Wiad Lek. 2020;73(7):1521-1527

\section{INTRODUCTION}

One of the goals of the UN Sustainable Development for 2016-2030 is to ensure a healthy life and promote well-being for all ages. On March 11 The World Health Organization declared COVID-19 a pandemic. The COVID-19 outbreak is an international concern in the public health. The virus, that first was detected in China on December 2019 , has now been detected in nearly 90 locations internationally and has been a significant impact on every aspect of lives countries.

The threat to global health has reached alarming proportions and has exposed a lack of national preparedness and international solidarity. The current role of achieving sustainable development goals is largely the provision of supplies for international trade in medicines and equipment. International law tends to be responsive, to war, atrocity or other disasters. So international law must tend to be responsive also to Coronavirus outbreak, because global co-operation in relation to health, technology, trade and investment is inevitable. Moveover, in an economically interdependent world, the importance of an improved legal framework for promoting international trade and investment is widely recognized.

\section{THE AIM}

The aim of the article is a theoretical and methodological justification for strengthening the role of international trade in medicines and equipment during the pandemic COVID-19, to establish the benefits of free trade, to develop important international trade policy priorities in this field.

\section{MATERIALS AND METHODS}

This study was conducted during January-April 2020. The main materials of the research are the norms of the WTO system of agreements, the decisions of 54 countries, that adopted temporary export restrictions on certain categories of critical medical supplies in response to COVID-19. Also this study is based on the empirical and analytical data of the WHO, WTO, the Organization for Economic Co-operation and Development, European Commission. The empirical and statistical data collected were processed, summarized, and analyzed using descriptive statistics capabilities. Totally 85 laws and papers were analyzed.

The key methods used in this research are data analysis, summarization and comparison. The data synthesis and analysis are the key value-added elements of this research, which could help to find out the role of international trade in medicines and equipment during the pandemic COVID-19. The method of system analysis made it possible to formulate the role and the priorities of international trade by medical supplies, devices and equipment during the pandemic COVID-19. The formal and legal method 
was used in the analysis of WTO system of agreement and legislative acts of different countries that adopted temporary export restrictions on certain categories of critical medical supplies in response to COVID-19. The statistical method, logical methods, and comparative analysis method were used to analyze the data from the WHO, WTO, the Organization for Economic Co-operation and Development, European Commission, as well as own findings.

\section{REVIEW AND DISCUSSIONS}

In today's world, one of the main drivers of economic development is international trade, which is the sphere of international economic relations and represents the sum total of foreign trade in goods; services, products of intellectual labour of all countries of the world. Today, international trade accounts for $80 \%$ of all international relations. In particular, international economic cooperation is one of the main factors influencing the level of global progress and economic development of each country today. Each country of the world conducts its own policy, creates its own economy, enters into a wide variety of international relations, carries out international trade, international transportation. Moreover, thanks to intensified trade ties, international relations have become stronger and world peace has move forwarded.

For the first time, world economies are facing an economic and financial crisis, caused not by distortions of market mechanisms, but by the direct consequence of a slowdown in health-related economic growth. The COVID-19 pandemic represents an unprecedented disruption to the global economy and world trade, poses a serious risk to the macroeconomics by halting production activities and shutting down supply networks. Plenty of countries around the world have either not paid sufficient attention to pandemic planning, having apparently presumed that such a scenario would ultimately become China's problem. However, COVID-19 knows no borders. Whether these borders are international frontiers, disciplinary boundaries, or industry sectors, it is clear that modern world need to work together to understand the wide-ranging implications of COVID-19. The dynamics of the pandemic are very different than other types of crises. The COVID-19 outbreak continues to grow rapidly around the world. The disease has been reported in 180 countries [1]. The appearance of a new infectious disease is always a complex situation, especially if it is an epidemic of significant extension or severity [2].

Today virtually all countries are finding themselves with decisions to make as they attempt to deal with the COVID-19 outbreak. The COVID-19 crisis has laid bare stark weaknesses in the health care systems, from the number of intensive-care beds to the size of the workforce, the inability to provide enough masks and to deploy testing in some countries, and deficiencies in the research for and supply of drugs and vaccines [3]. The COVID-19 pandemic has brought considerable attention to trade in medical products and supplies, and specifically trade in products for prevention, testing and treatment. Medical products, in general, are widely spread in different Chapters of the
Harmonized System (HS) classification. A set of products that are considered relevant to COVID-19 prevention and medical treatment in general are categorized into four main groups: 1. Medicines (Pharmaceuticals) - including both dosified and bulk medicines; 2. Medical supplies - refers to consumables for hospital and laboratory use (e.g. alcohol, syringes, gauze, reagents, etc); 3. Medical equipment and technology; 4. Personal protective products - hand soap and sanitizer, face masks, protective spectacles. The protective garments for surgical/medical use are not included in the analysis, because it is impossible to distinguish them from general clothing product in the HS classification.

A subset of medical products has been frequently mentioned by governments, international organizations and in news reports as in short supply for the fight against COVID-19. These include: disinfectants/ sterilization products; face masks; gloves; hand soap and sanitizer; patient monitors and pulse oximeters; protective spectacles and visors; sterilizers; syringes; thermometers; ultrasonic scanning apparatus; ventilators, oxygen masks; $\mathrm{X}$-ray equipment; and other devices such as computer tomography apparatus [4]. World experience shows that there is a shortage of essentials such as face masks, test kits, personal protective equipment, fans, ventilators and other items needed by health and safety personnel, has reached crisis levels worldwide.

Medical supplies, devices and equipment play an important role in helping doctors analyze and monitor patients. They can also save the life of thousand people. For the immediate response to the current wave of the pandemic, policy should focus on the availability of sufficient diagnostic tests and emergency supplies. This can be done through international cooperation in purchasing, to avoid excessive purchases and stockpiling in one place creating shortages in others. It also requires demand planning, monitoring supply chains and ensuring that sufficient funds are allocated procuring basic goods that are simple to produce but for which margins and manufacturing capacity may be low $[5,9]$.

The World Health Organization (hereinafter referred to as $\mathrm{WHO}$ ) has warned that Shortage of personal protective equipment endangering health workers worldwide, and severe and mounting disruption to the global supply of personal protective equipment is putting lives at risk from the new coronavirus and other infectious diseases [6].

In the light of the above, international trade is gaining importance role in ensuring the availability and affordability of vital medicines, medical products and health care services, particularly among its most vulnerable members. International trade represents the total amount of exports and imports of a country and constitutes the most important component of the balance of payments [7]. Trade policies are powerful drivers of the distribution of power, money, and resources, which affect people's daily living and working conditions, their health-related preferences and behaviors, and ultimately their health outcomes [8].

It is against this background that international trade in medical devices and equipment are increasingly playing more important roles in the implementation of international development goals. The priority for governments and the 
global community is to prevent people from contracting the disease and to cure those who do. Many countries source these medical supplies from abroad and so trade policy stance becomes part of national policy responses to the Coronavirus.

Increased trade and trade liberalization is a defining feature of globalization, directly and indirectly affecting health and health systems. Diffusion of health technologies through global trade has contributed greatly to worldwide health improvements [9]. Trade policies are powerful drivers of the distribution of power, money, and resources, which affect people's daily living and working conditions, their health-related preferences and behaviors, and ultimately their health outcomes [8].

Today international trade is crucial to ensuring access to medicines and other medical products. The global medical devices market offers tremendous opportunity for manufacturers, as well as significant challenges, for government policymakers seeking to support export competitiveness in overseas markets. In spite of the fact that trade in these products collectively amounts to $1.7 \%$ of world merchandise trade, world exports of medical products grew by $9 \%$ in 2018 and 6\% in 2019, from $\$ 859$ billion in 2017 to around $\$ 995.8$ billion total world exports in 2019 [10]. The United States, the European Union (hereinafter referred to as EU), Japan, and China together account for about 90 percent of global production and consumption of medical devices [11]. China is the top exporter of face masks with $25 \%$ share China supplied 25\% world exports of face masks in 2019, and together with Germany and the US, the three contribute to almost half of the world face mask supply. Singapore, US, Netherlands, and China export more than half the world's respirators and ventilators Breathing apparatus, including respirators and ventilators, are supplied by a small number of Members notably, Singapore which has 18\% market share, followed by the US with $16 \%$, Netherlands $10 \%$ and China 10\% [10]. For example, the main destination for EU exports of medicinal and pharmaceutical products in 2019 was the United States (accounting for 32\% of EU exports of these products), followed by Switzerland (11\%), the United Kingdom (10\%), China (6\%), Russia and Japan (both 4\%). Germany was the largest exporter of medicinal and pharmaceutical products ( $€ 47$ billion), followed by Ireland ( $€ 32$ billion), Belgium ( $€ 28$ billion), the Netherlands ( $€ 22$ billion), France ( $€ 17$ billion) and Italy ( $€ 16$ billion) [12].

The immediate response for COVID-19 has been to break interconnections as a measure to contain and mitigate the virus. This reduces the ability for countries to cooperate, and creates further incentives for countries to implement export bans and anticipate global shortages. These bans on medical supplies have become as infectious as the virus itself. Regrettably we can observe how governments worldwide have started to introduce controls on certain trade activities, particularly relating to the export of medical products and protective equipment, in response to the virus outbreak. Since the beginning of 2020 the governments of some nations have taken steps to ban or limit the export of medical equipment (such as masks) and medicines and their ingredients.
According to the Global Trade Alert 54 governments had introduced export curbs on key medical supplies since the beginning of the year [13]. Countries restricting pandemic-related exports include Albania, Argentina, Australia, Brazil, Colombia, India, Kazakhstan, Pakistan, Paraguay, South Korea, Thailand, Vietnam [14]. Of the 164 World Trade Organization (hereinafter referred to as WTO) members, only 50 do not tax imported medical devices and 23 levy duties at less than $3 \%$ of shipment value. Sensibly, 76 nations do not tax imported medicines. But only 37 WTO members refrain from taxing imports of disinfectant. For soap just nine WTO members permit duty-free imports $[15,1]$. The EU has banned for member states the export of personal protective equipment, including face shields, surgical masks and gowns, without export authorization. Regarding trade with non-EU countries, the European Commission issued an Implementing Regulation requiring that exports of specified personal protective equipment, whether or not originating in the European Union, to nonEU countries, be subject to authorization. As specified in a newer Guidance note, this includes all non-EU countries, including the United States and the EU's preferential trade partners, with the exception of the four member states of the European Free Trade Association (Iceland, Liechtenstein, Norway, and Switzerland), certain overseas countries and territories listed in Annex II of the Treaty on EU, as well as the Faeroe Islands, Andorra, San Marino, and Vatican City. The United Kingdom is considered to be an EU country in this context. Exports of certain quantities of specific products may be authorized under specific circumstances such as to ensure assistance to third countries and depending on the needs of the Member States [16].

In today's world, what one country did can have an impact on others. The primary aim of those protectionist policies is protect the provision of public health [7]. However, cutting exports to many countries is risky for two reasons. First, it endangers countries that are also suffering from COVID-19, especially those that rely heavily on supplies. Second, it could endanger the country itself if foreign partners are unable or unwilling to supply with the medical products it needs and cannot produce. Retaliation by foreign partners could even lead to the breakdown of regional and global value chains for essential products. They contribute to the deterioration of the international trade climate at a time when international cooperation is most needed because of the global pandemic. For example, the 25 nations that export significant amounts of medical ventilators include one just nation in Latin America and no nations in Africa, the CIS region, the Middle East, and South Asia. Given the sophisticated technology found in cutting-edge ventilators, it is unlikely that there are local producers in these countries capable of meeting global standards. Therefore, billions of people in developing countries are dependent on international trade for access to this critical technology, used to help patients suffering from advanced stages of COVID-19 [17].

Moreover, as developing countries have a considerable effect on the world market, their decisions to implement 
policies to backing their exports or substitute imports will have an impact on all over the world. It should be mentioned here that protectionist policies to international trade have impacts on both an implementing country and other trading countries in a globalized economy. Indeed, the country that implements protectionist policies can influence the world trade according to its size. If that country is a small scale one, the implemented tariffs increase domestic prices while not affecting the world's supply-demand balance. On the other hand, large scale economies have a huge impact on the world economy, and thereby, influence other countries adversely and lead to welfare loss when they employ protectionist policies.

Experience shows that no country can solve the world's problems alone, no country is entirely self-reliant for the products and equipment it needs for its public health systems. In this context, it is naturally worrying that developments have led to a situation in which many countries have difficulty with personal protective equipment, face masks, fans and other items that help to combat coronavirus. For our opinion, regrettably emergency actions must not impose unwarranted restrictions on trade. The government response to the global crisis has further heightened economic inequalities an important question which arises in this connection is the effect of the agreements WTO.

According the Resolution of the United Nations General Assembly "70/1 Transforming our World: the 2030 Agenda for Sustainable Development" international trade is a mechanism for the implementation and activation of global partnerships. A universal, rules-based, non-discriminatory and equitable multilateral trading system is the best modality to advance trade among member States and can promote the economic growth and advancement of developing countries. Through transparent, non-discriminatory and fair rules for trade regulation, the promotion of exports by developing countries, duty-free and quota-free access to the markets of the least developed countries, trade should promote inclusive development, environmental sustainability and economic growth [18].

Today, the regulation of international trade is carried out through the WTO system of agreements. The WTO acknowledges that health is a legitimate policy goal and provides an exception rule that is contained in most trade agreements, which allows member states to introduce health-related policy measures provided they are deemed necessary to protect human or environmental health and safety and are not introduced to act as a barrier to trade [8]. During the 20 years of its existence, the WTO has transformed trade into a tool for socio-economic growth, sustainable development, environmental protection, fostering innovation and creating fair market conditions for business. The complexity of relationships and business structures, the change of traditional paradigms of world trade, economic crises in this situation of spread Covid-19 pandemic significantly complicate the functioning of the organization, forcing the latter to respond in time to change.

The WTO Rules permit Members to take actions to protect the health and safety of their citizens, in particular in particular in the General Agreement on Tariffs and Trade (GATT 1947) [19], the General Agreement on Trade in Services [20], the Agreement on Trade-Related Aspects of Intellectual Property Rights [21], the Agreement on the Application of Sanitary and Phytosanitary Measures (SPS Agreement) [22], the Agreements on technical barriers to trade (TBT Agreement) [23].

One of the key rules affecting exports is Article XI of the General Agreement on Tariffs and Trade (GATT 1947): on General Elimination of Quantitative Restrictions which specifies that 'no prohibitions or restrictions other than duties, taxes or other charges, whether made effective through quotas, import or export licenses or other measures, shall be instituted or maintained by any contracting party on the importation of any product of the territory of any other contracting party or on the exportation or sale for export of any product destined for the territory of any other contracting party'. Certain exceptions to this general prohibition are allowed under Article XI: of the GATT. In particular, temporary prohibitions or restrictions were allowed to relieve critical shortages of foodstuffs or other products essential to the exporting contracting party. Article XX contains an exception from these commitments for actions taken that are "necessary to protect human... life or health," subject to the proviso that "such measures are not applied in a manner which would constitute a means of arbitrary or unjustifiable discrimination between countries where the same conditions prevail, or a disguised restriction on international trade..." [19; 24].

The Agreement on Trade-Related Aspects of Intellectual Property Rights also provides members with flexibilities to ensure that life-saving drugs are available and affordable for their citizens. Among other tools, governments can use WTO-compliant compulsory licensing procedures in cases where patented drugs have been unaffordable or not widely available [21]. The Agreement on the Application of Sanitary and Phytosanitary Measures establishes that members have the right to restrict trade by taking measures necessary for the protection of human, animal or plant life or health. These measures should only be applied to the extent necessary to achieve their objectives, be based on scientific principles and be supported by scientific evidence. In situations where relevant scientific evidence is insufficient, members may provisionally adopt measures on the basis of available pertinent information [22]. The Agreements on technical barriers to trade aims to ensure that technical regulations, standards and conformity assessment procedures are non-discriminatory and do not create unnecessary obstacles to trade. At the same time, it recognizes WTO members' right to implement measures to achieve legitimate policy objectives, such as the protection of human health and safety [23].

All these agreements require WTO members to notify others of any new or changed requirements which affect trade, and to respond to requests for information on new or existing measures. In addition, these measures should be applied in such a way that there is no discrimination between WTO members and should not be a disguised restriction on international trade. 
The WTO rules provide a wide scope for Member States for trade relations. At the same time, membership in the WTO imposes on the Member State specific obligations, which in content can be fairly conditionally grouped into the following groups: first, these are changes affecting the national trade regime as a whole (import and export duties, rules and procedures for customs valuation and origin of goods, principles for applying safeguards in trade, etc.); secondly, the introduction at national level of international principles and procedures for the application of technical norms and standards, sanitary and phytosanitary measures, etc., i.e. tools for ensuring consumer safety; thirdly, it is a change of the national regime of regulation of certain sectors of industry and agriculture, service sector.

An analysis of the WTO agreements makes it possible to conclude that these agreements nothing in the WHO rules prevents a roll-back of export restrictions, nothing subsidies from being granted to increase the global supply of medical products needed to respond to the COVID-19 pandemic. Also additional flexibility in the WTO's Agreement on Trade Related Intellectual Property can facilitate countries' access to affordable life-saving medicines.

Along with this there are several other important issues: whether tariffs can be eliminated on medical supplies, whether export restrictions on these products can be lifted if already imposed, and eliminated if already in place, and whether subsidies are needed to spur necessary production and economic activity? Progress in answering these questions has been notably slow. If there is to be a rule of thumb to follow in answering these questions, it should be to remind all developed countries that the COVID-19 pandemic is a challenge for societies around the world, which means that we all have a shared responsibility for this together. The human costs of the Coronavirus pandemic are already immeasurable and all countries need to work together to protect people and limit the economic damage.

It is too early to gauge the full economic and trade effects of the Coronavirus outbreak. There will undoubtedly be many unanticipated consequences of this viral outbreak, economically, politically and from a global health response perspective. The domestic policies need to be supported by maintaining international trade and cooperation, which are essential to defeating the pandemic and maximizing the chances of a quick recovery. Bearing in mind that the reactivation of economic growth and sustainable development in all countries requires, inter alia, a dynamic and a supportive international economic environment, three important priorities should be identified.

The first priorities have sensibly been to combatting this pandemic calls for a transparent, robust, coordinated, large-scale and science-based global response in the spirit of solidarity [25]. The COVID-19 pandemic has highlighted the need for greater cooperation and efforts to reduce barriers to trade, including through increased mutual recognition agreements. These are the actions that leaders should be taking now. Instead of restricting the international trade by medical supplies, devices and equipment, it is necessary, on the contrary, to cooperate globally around the deployment of life-saving medical supplies, publicly commit all countries not to implement export bans or limits on relevant medical supplies or reverse existing export bans on medical supplies needed to tackle the Coronavirus. The international system for regulating international trade by medical supplies, devices and equipment must address the needs of the rich and the poor. When patented medicines are not affordable, governments must act [26]. The coronavirus crisis has highlighted the challenge of protecting the health of the population whilst avoiding disruptions to the free movement of persons, and the delivery of goods. The next natural progression is for the governments to cooperate with the medical industry to boost production and set a ceiling price for these items. Governments and industry will need to come to an agreement: during a pandemic, vaccines and antivirals can't simply be sold to the highest bidder. They should be available and affordable for people who are at the heart of the outbreak and in greatest need. Not only is such distribution the right thing to do, it's also the right strategy for short-circuiting transmission and preventing future pandemics [27]. Governments should develop incentives for industry to ramp up production. This includes easing restrictions on the export and distribution of personal protective equipment and other medical supplies. In this way we can observe how the European Commission has sought to help the industry address the urgent need for health care during the pandemic. In the Commission Recommendation (EU) 2020/403 of 13 March 2020 on conformity assessment and market surveillance procedures within the context of the COVID-19 threat The European Commission asked the European Committee for Standardization (CEN) and the European Committee for Electrotechnical Standardization (CENELEC) to provide a number of European standards for certain medicines and personal protective equipment [28].

The second priority is to control all trade measures countries have taken in response to the COVID-19outbreak. For the realization this goal should govern the conduct of policies towards medical supplies the COVID-19: international trade by medical supplies, devices and equipment should be transparency and coherence, do not harm. Notwithstanding all the challenges, the WTO will remain an effective regulator of international trade at the multilateral level, and the authorities, business and citizens will increasingly feel the beneficial effects of international trade and the socio-economic development of states.

Nowadays the WTO, the United Nations Department for Economic and Social Affairs and the International Trade Centre have been created the web page "ePing" for allowing users to receive daily or weekly email alerts about new sanitary and phytosanitary (SPS) information or technical barriers to trade (TBT) information notifications and to search for existing measures covering products or markets of interest to them. WTO Members are normally required to inform each other when planning to change product requirements and provide an opportunity for other Members to comment on these requirements. They do so by submitting a two-page info sheet on the regulation with 
information on products covered, a brief summary of the regulation and the deadline for providing comments. These info sheets, called SPS or TBT notifications, are sent to ePing users based on their interests. Today there are more than 63000 notifications [29].

The third priority is to bring together in a global form measures and procedures to eliminate this phenomenon. International cooperation is essential to deal with the health and economic impact of the COVID-19virus. Global cooperation is the only way countries can minimize the disruption that COVID-19 leaves in its wake. International cooperation is critical to ensure medical supplies ultimately reach the most vulnerable populations. Close coordination between action by states and action by the international community is a key element of this crisis, in particular to ensure that essential commodities needed to mitigate health risks from outbreaks can reach anyone who needs them. It is important to develop policy mechanisms to improve common approaches to ensure the production, storage, accessibility and rational use of medicines, and not to take unilateral measures that restrict the free movement of essential medical supplies.

\section{CONCLUSIONS}

While the COVID-19 pandemic is first and foremost a health crisis, its implications are more far-reaching and could threaten global peace and security. Overall, a global trade cooperation is a crucial and needed solution to fight COVID-19. The human costs of the Coronavirus pandemic are already immeasurable and all countries need to work together to protect people and limit the economic damage. In the global cooperation all counties should commit to take all necessary health measures and seek to ensure adequate financing to contain the pandemic and protect people, to continue working together to facilitate international trade and coordinate responses in ways that avoid unnecessary interference with international traffic and trade. All countries need to work to ensure the flow of vital medical supplies, and work to resolve disruptions to the global supply chains, to support the health and wellbeing of all people. Sharing information and facilitating the flow/ movement of medical products can be one of many forms of global cooperation in sharing global resources to combat this pandemic. It should, in particular, seek to promote effective implementation of the existing commitments and agreements in the area of international economic and social development.

\section{REFERENCES}

1. Online Coronavirus COVID-19 Global Cases [Internet]. Baltimore, MD: Johns Hopkins University, 2020. [cited 2020 March 25]. Available from: http://www.omim.org/ https://gisanddata.maps.arcgis.com/apps/ opsdashboard/index.html\#/bda7594740fd40299423467b48e9ecf6

2. Trilla A. One world, one health:The novel coronavirus COVID-19epidemic. Medicina Clínica (English Edition). 2020; 154(5):175-177. doi:10.1016/j. medcle.2020.02.001

3. The Organization for Economic Co-operation and Development (OECD). New OECD outlook on the global economy [Internet]. Paris: 2020. [cited 2020 March 26]. Available from: http://www.oecd.org/coronavirus/en/
4. World Customs organization/ organization mondiale des douanes. HS Classification reference for Covid-19 medical supplies. [Internet]. Belgium: 2020. [Updated 10 April 2020]. Available from: http://www. wcoomd.org/-/media/wco/public/global/pdf/topics/nomenclature/ covid_19/hs-classification-reference_en.pdf? la=en

5. The Organization for Economic Co-operation and Development (OECD): Beyond Containment: Health systems responses to COVID-19in the OECD [Internet]. Paris: OECD; 2020. [Updated 25 March 2020]. Available from: https://read.oecd-ilibrary.org/view/?ref=119_119689ud5comtf84\&title=Beyond_Containment:Health_systems_ responses_to_COVID 19_in_the_OECD

6. World Health Organization (WHO). Shortage of personal protective equipment endangering health workers worldwide. [Internet]. Geneva: WH0;2020. [updated 2020 March 3]. Available from: https://www.who. int/news-room/detail/03-03-2020-shortage-of-personal-protectiveequipment-endangering-health-workers-worldwide

7. Merve A. Demir, Sepli A. The effects of protectionist policies on international trade. International Journal of Social Sciences. 2017; 3(2):136-158. doi: 10.20319/pijss.2017.32.136158.

8. Friel S., Hattersley L., Townsend R. Trade Policy and Public Health. Annual Review of Public Health. 2015; 36(1):325-344. doi: 10.1146/ annurev-publhealth-031914-122739.

9. Missoni E. Understanding the Impact of Global Trade Liberalization on Health Systems Pursuing Universal Health Coverage. Value in Health. 2013; 16(1):14-18. doi: 10.1016/j.jval.2012.10.002.

10. World Trade Organization (WTO). Trade in medical goods in the context of tackling COVID-19. Paris:WT0;2020. [Updated 2020April 10]. Available from: https://www.wto.org/english/news_e/news20_e/rese_03apr20_e.pdf

11. United States International Trade Commission. Medical Devices and Equipment: Competitive Conditions Affecting U.S. Trade in Japan and Other Principal Foreign Markets. Washington: Investigation No. 332-474. Publication 3909. 2007. [Updated March 2007]. Available from: https://www.usitc.gov/publications/332/pub3909.pdf

12. Eurostat. European Commission. International trade in goods. [Internet]. Luxembourg: European Commission; 2019. [updated 2020 March 20]. Available from: https://ec.europa.eu/eurostat/web/internationaltrade-in-goods/data/database

13. Global Trade Alent. Tackling COVID-19Together [Internet]. Switzerland: University of St. Gallen; 2020. [updated 2020 March 23]. Available from: https://www.globaltradealert.org/reports/51

14. World Health Organization (WHO). COVID-19and world trade [Internet]. Geneva:WHO; 2020. [updated 2020 March 20]. Available from https:// www.wto.org/french/tratop_f/covid19_f/covid19_f.htm

15. Global Trade Alent. Tackling Coronavirus: the trade policy dimension [Internet]. Switzerland: University of St. Gallen; 2020. [cited 2020 March 11]. Available from: https://www.globaltradealert.org/reports/50.

16. Commission Implementing Regulation (EU) 2020/402 making the exportation of certain products subject to the production of an export authorization [Internet]. EU: Official Journal of the European Union, L 077I, [cited 2020 March 15]. Available from: https://eur-lex.europa.eu/ legal-content/EN/TXT/HTML/?uri=0J:L:2020:077l:FULL\&from=EN

17. Global Trade Alent. Tackling Together [Internet], Switzerland: University of St. Gallen; 2020. [updated 2020 March 23]. Available from: https:// www.globaltradealert.org/reports/51

18. Resolution Transforming our World: the 2030 Agenda for Sustainable Development [Internet]. United States the General Assembly. [cited 2020 March 20]. Available from: https://www.unfpa.org/resources/ transforming-our-world-2030-agenda-sustainable-development 
19. The General Agreement on Tariffs and Trade (GATT 1947). Oct. 30, 1947. [Internet]. Paris: World Trade Organization. [cited 2020 March 15]. Available from: https://www.wto.org/english/docs_e/legal_e/ gatt47_01_e.htm

20. The General Agreement on Trade in Services (GATS). Apr. 15, 1994. [Internet]. Paris: World Trade Organization. [cited 2020 March 15]. Available from: https://www.wto.org/english/docs_e/legal_e/26-gats.pdf

21. The Agreement on Trade-Related Aspects of Intellectual Property Rights (TRIPS) Apr. 15, 1994. [Internet]. Paris: World Trade Organization. [cited 2020 March 15]. Available from: https://www.wto.org/english/docs_e/ legal_e/27-trips.pdf

22. The Agreement on the Application of Sanitary and Phytosanitary Measures (SPS Agreement). Apr. 15, 1994. [Internet]. Paris:World Trade Organization. [cited 2020 March 15]. Available from: https://www.wto. org/english/tratop_e/sps_e/spsagr_e.htm

23. The Agreements on technical barriers to trade (TBT Agreement). Apr. 15, 1994. [Internet]. Paris: World Trade Organization. [cited 2020 March 15]. Available from: https://www.wto.org/english/docs_e/ legal_e/17-tbt.pdf

24. Laird S. Export policy and the WTO. The Journal of International Trade \& Economic Development, 1999; 8(1):73-88. doi: 10.1080/09638199900000006

25. World Trade Organization (WTO) Statement Extraordinary G20 Leaders' Summit Statement on COVID-19 [Internet]. Paris:WT0;2020. [Updated 2020 March 26]. Available from https://www.wto.org/english/news_e/ news20_e/dgra_26mar20_e.pdf

26. Abbott, F. M. The WTO Medicines Decision: World Pharmaceutical Trade and the Protection of Public Health. The American Journal of International Law. 2005; 99(2):317. doi: 10.2307/1562501

27. Gates, B. Responding to Covid-19 - A Once-in-a-Century Pandemic? New England Journal of Medicine. 2020. doi:10.1056/nejmp2003762

28. Commission Recommendation (EU) 2020/403 on conformity assessment and market surveillance procedures within the context of the COVID-19 threat. [Internet]. EU: Official Journal of the European Union LI 79/1. [Updated 2020 March 13]. Available from: https://eur-lex.europa.eu/ legal-content/EN/TXT/?qid=1584654491688\&uri=CELEX:32020H0403
29. EPing - track product requirements in export markets. [Internet]. [cited 2020 March 20]. Available from: https://www.epingalert.org/en

\section{ORCID and contributionship:}

Farouq Ahmad Faleh Alazzam: 0000-0002-7817-9704 A,D,F Ali Jabbar Saleh: 0000-0003-1975-1173 B,E,F

Khaled Khalaf Abed Rabbo Aldrou: 0000-0001-7559-4403 $3^{\text {B,E,F }}$

\section{Conflict of interest:}

The Authors declare no conflict of interest.

\section{CORRESPONDING AUTHOR Farouq Ahmad Faleh Alazzam \\ Faculty of Law Jadara University, Amman str., P.O. Box (733), Irbid, 21110, Jordan tel: 00962790836563 \\ e-mail:alazzamfarouq@yahoo.com}

Received: 21.03 .2020

Accepted: 19.06 .2020

\footnotetext{
A - Work concept and design, B - Data collection and analysis, C - Responsibility for statistical analysis,
} D-Writing the article, $\mathbf{E}$ - Critical review, $\mathbf{F}$ - Final approval of the article 